MICHAEL A. PENMAN

\title{
The Scots at the Battle of Neville's Cross, 17 October 1346
}

David II (1329-71) was a king unable to celebrate military victory against England, either of his own or of his father's making. David and his royal host succumbed to an improvised English militia led by the archbishop of York at Neville's Cross on parkland outside Durham on 17 October 1346. As a result of that crushing defeat, David's commemoration of each anniversary of the most famous triumph of his father, Robert I, became tainted: for after 1357 Edward III would insist that the Scots pay David's ransom annually on 24 June, St John the Baptist's day, but also the anniversary of Bannockburn. Ironically, however, David's capture in 1346 meant that Neville's Cross was far more influential in bringing about peace between the houses of Bruce and Plantagenet and their realms than any of the other pitched battles of the Scottish Wars of Independence. Although it would take over a decade to reach a settlement - and require England's additional capture of Scotland's ally, John II of France, at Poitiers (September 1356) - the 'battle of Durham' is now rightly held as having had telling diplomatic consequences in both the British Isles and mainland Europe. ${ }^{1}$

To mark the $750^{\text {th }}$ anniversary of the battle, the strategies and leadership displayed in the field during the four or so hours over which it was fought have received fresh historical attention. Previously overlooked chronicle and letter accounts of the battle have been brought together to give a clearer picture of the winning combination of archery, infantry and cavalry tactics deployed by quick-thinking English captains. The Scottish leaders' fatal choice of poor ground and tactics have also become apparent, providing a strong contrast to Robert I's masterful exploitation of the terrain around Stirling in $1314 .^{2}$

1 Regesta Regum Scottorum VI: The Acts of David II, 1329-71 [RRS, vi], ed. B. Webster (Edinburgh, 1982), nos. 148-150; J. Campbell, 'England, Scotland and the Hundred Years War in the fourteenth century', in J. R. Hale, J. R. L. Highfield and B. Smalley (eds.), Europe in the Late Middle Ages (London, 1965), 184-216, reprinted in C. J. Rogers (ed.), The Wars of Edward III: Sources and Interpretations (Suffolk, 1999), 207-230; A. A. M. Duncan, 'Honi soit qui mal y pense. David II and Edward III, 1346-52', ante, lxvii (1988), 113-41; J. Sumption, The Hundred Years War - Vol I: Trial by Battle (London, 1990), 551-3.

2 D. Rollason and M. Prestwich (eds.), The Battle of Neville's Cross (Stamford, 1998), which includes a section of translated chronicle and letter accounts of the battle [hereafter Neville's Cross]; K. DeVries, Infantry Warfare in the Early Fourteenth Century: Discipline, Tactics and Technology (Suffolk, 1996), chs. 4, 6, 9, 13-14; C. J. Rogers and M. C. Buck, 'The Scottish invasion of 1346', Northern History, xxxiv (1998), 51-82, which also includes chronicle/letter extracts about the battle.

MICHAEL A. PENMAN is Lecturer in Scottish History at the University of Stirling. He is grateful to Norman Macdougall, Michael Brown and Stephen Boardman for their comments on earlier drafts of this article. 
But a further factor central to any explanation of the 'joyous' English victory, and the terrible cost of Scottish defeat, was the turbulent background of Scottish crown-magnate politics in the years preceding the battle. In the first five years of his active adult rule, after seven years as an adolescent in exile in northern France, David II was able to reward and win the loyal support of an impressive majority of the Scottish magnate community: most of these Scots stuck by him in battle, being either slain or captured at his side. Yet the heavy price of building up this support for the personal monarchy of the second Bruce king was the dangerous alienation of a smaller group of key Scottish nobles.

In autumn 1346 the desertion from David's host by three magnates in particular - with their armed followings in tow - must have had a fatally compromising effect upon any chance that superior Scottish numbers (almost 2:1) could have won the day. Both English and Scottish chroniclers concur in stating that at the muster of the northern contingent of the Scottish host at Perth in late September 1346, William, Earl of Ross, murdered sacrilegiously a local rival and then fled. The campaign went ahead, but at the crucial moment, when the tide of battle seemed to turn against the Scots on 17 October, Robert the Steward, David II's nephew and heir presumptive, along with Patrick Dunbar, Earl of March, withdrew the third and last Scottish division from the fray, perhaps - as Alexander Grant has suggested - taking with them most of the Scottish army's riderless horses and without ever engaging the enemy. The contemporary Lanercost chronicler almost spat that:

if one was worthless, the other was nothing ... [the Steward] overwhelmed by cowardice, broke his promise to God that he would never wait for the first blow in battle, and he fled with [March]. Turning their backs, these two fled valiantly with their force and entered Scotland unscathed, and so they led the dance, leaving David to dance his own tune. ${ }^{3}$

But in 1346 can the charge of dangerous political brinkmanship in domestic politics be added to those of David's youth, over-confidence and military inexperience? Had the king given these men absolutely no reason to stay and fight for him?

3 Chron. Lanercost extract translated by M. Arvanigian and A. Leopold in Neville's Cross, 138-9; Chron. Lanercost, 330-51; Chron. Fordun, ii, 358; Chron. Wyntoun, vi, 170-8; Chron. Bower (Watt), vii, 249-53; 'The Pipewell Chronicle Account', British Library [BL], Cotton MSS Caligula A XIII, fol. 15/Harleian MSS, 624 fol. 34v - transcribed and translated in Rogers and Buck, 'The Scottish invasion of 1346', 78-81; A. Grant, 'Disaster at Neville's Cross: The Scottish point of view', in Neville's Cross, 32-3. The Anonimalle Chronicle, 1333-1381, asserts that: 'Robert Stewart, steward of the Scots, Earl Patrick and many of the rearguard took to flight without giving or receiving a blow from sword or lance. But the English heard of their flight and quickly gave chase. In this pursuit a great number of the Scots were captured and killed' (Neville's Cross, 145). The chronicle of Meaux Abbey, Yorkshire, states that: 'The Earl of Dunbar, Patrick, and the Steward of Scotland, thinking that their men were losing and the English winning, fled straightaway' (ibid., 147-8). 
In early June 1341, David II, aged seventeen, returned from his refuge at Château Gaillard in Normandy to a Scottish kingdom in which Robert Steward as king's lieutenant (or 'guardian' according to the chroniclers), along with several other young, ambitious Scottish knights, had recovered all but a residue of Scottish territory and castles from Anglo-Balliol occupation. In this company, the young king had his work cut out to assert his personal Bruce stamp over government and the continued prosecution of war.

Tensions between David and his close advisors on the one hand and the Steward on the other had already become apparent during his exile. David's chief counsellor, John Randolph, Earl of Moray and Lord of Annandale, second son of Sir Thomas Randolph the Guardian (1329-32), had challenged the Steward's lieutenancy and control of royal finances at a heated Parliament in Fife in 1335. After 1338, David and his court in exile in France had sought to direct Scottish domestic and diplomatic affairs, over-riding the Steward. ${ }^{4}$ Now in mid-1341 David, young and childless, returned to find that his heir presumptive and nephew, the Steward, who was eight years his senior, had at least three healthy infant sons and a large armed following drawn not only from his own Clydeside lands and west coast allies like the Campbells of Lochawe, but from many Lowland Scots from whom he had otherwise taken homage in David's name since 1338. The Steward had also amassed considerable experience of national leadership in war and administration and begun to expand his territorial interests in the regional vacuums created by the fighting. ${ }^{5}$

So suspicious of each other had David and the Steward become that it is possible they avoided one another after the royal party made a surprisingly low-key landfall in Scotland about 2 June 1341 at Inverbervie on the Angus coast, just north of Dundee. In his first few weeks of ayres, the king clearly limited his movements to a comfort-zone in the north-east which had sustained his court in exile and where close supporters such as his aunt, Christian Bruce, widow of Sir Andrew Murray of Bothwell and Garioch (David's lieutenant 1335-8), controlled key strong-points like Kildrummy castle and Aberdeen. David may have first encountered the Steward only about 18 July 1341 at Stirling castle where he visited the Scots' siege of the English garrison. ${ }^{6}$

But at Stirling, David may also have encountered William, Earl of Ross, another magnate who had fought for the Bruce cause since 1332 but very definitely advanced his own interests. ${ }^{7}$ Between 1329 and 1331

4 Chron. Fordun, ii, 350; Chron. Bower (Watt), vii, 107-09, 145; ER, i, 435-6; R. Nicholson, Scotland: The Later Middle Ages (Edinburgh, 1974), 132-40.

5 S. Boardman, The Early Stewart Kings: Robert II and Robert III, 1371-1406 (East Linton, 1996), 6-7; M. Penman, The Bruce Dynasty in Scotland: David II, 1329-71 (East Linton, forthcoming), ch. 2.

6 RRS, vi, nos. 24-33; Chron. Wyntoun, vi, 136; Chron. Bower (Watt), vii, 141-45; Calendar of Documents relating to Scotland [CDS], iii, no. 1383.

7 Earl William's father, Hugh, was killed fighting for the Bruce Scots at Halidon Hill, 1333 - William may have been king's lieutenant in the north sometime in the 1330s; Chron. Wyntoun, vi, 134-5, relates that the Steward and Ross squabbled at the 1339 siege of 
Thomas Randolph as guardian had had cause summarily to punish wrongdoing in the north, perhaps the fallout from Ross's feuds with the Mackenzies of Kintail and other kindreds. But by 1339 at least, Ross had assumed the Randolph office of justiciar north of Forth during the English captivity of John Randolph (late 1335 to early 1342) and was advancing designs on the northern earldoms of Caithness and Orkney. Neither Ross, the Steward nor the earl of March were recorded as royal charter witnesses from 2 June 1341 until their unavoidable attendance at David's first Parliament at Scone in September of that year. ${ }^{8}$

By the time the Estates had assembled there, however, David was three months into a programme of renewed royal patronage and attempts to assume personal sway over the Scots in war. His resettlement of lands and offices between 1341 and 1346 was from the first characterised by a desire to attract for the Crown the support and loyalty of noticeably lesser magnates, knights and esquires, men who had fought for the Bruce Scots since 1332 and in some cases earned a strong reputation as 'flowers of chivalry'. David sought to use patronage to draw these men to look to the Crown - much in the way his father had done after Bannockburn - so as to ensure that he had loyal men in place in the localities. But he also looked to a good many men as a counter-balance to what he by now perceived as the unreasonable influence of selfinterested magnates like the Steward and Ross. Yet, at the outset, as Michael Brown has recently shown, this involved a necessary admission by David that the regional influence of certain up-coming men, established using potent military lordship to exploit the power vacuums resulting from war in the 1330 s, could not be ignored by the Crown if it was to secure sufficient allies to overawe both internal and external opponents. ${ }^{9}$

So it was that much of David's early favour was given to Sir William Douglas of Lothian, a third cousin and pretender to the role of the good Sir James Douglas (d. 1330), essentially validating William's displacement of Anglo-Balliol control of much of the Lothians and the east and middle marches since 1338. David allowed Douglas and his kindred to maintain control of the key offices of sheriff and castle-keeper at Edinburgh and sheriff of Perth, as well as general control of the Douglas

7 (continued) Perth - certainly, c.1341 Ross's allies, the Munros, seem to have raided the royal Perthshire thanage of Strathardle, lands coveted by the Steward (British Library [BL], Add MSS 19,797 f. 3).

8 Chron. Bower (Watt), vii, 57-61, for Randolph in the north executing wrongdoers; for Ross as justiciar, see Registrum de Dunfermlyn, 259; A. Mackenzie, A History of the Mackenzies (Inverness, 1894), 49-50; for Ross's interest in the far north, see B. Crawford, 'The Earls of Orkney-Caithness and their relations with Norway and Scotland, 1158-1470' (Ph.D. Thesis, University of St Andrews, 1971), 29-39, 178-83. RRS, vi, no. 33, and Acts of the Parliaments of Scotland [APS], i, 512, for Parliament.

9 For David's patronage in general, see M. Penman, 'The kingship of David II of Scotland, 1329-71' (Ph.D. Thesis, University of St Andrews, 1999), ch. 4; M. Brown, The Black Douglases: War and Lordship in Late Medieval Scotland, 1300-1455 (East Linton, 1998), ch. 2 , and M. Brown, 'The development of Scottish Border lordship, 1332-58', Historical Research, lxx (1997), 1-22. 
family lands amassed in the marches since 1306. But David also added to this regional empire with grants of Eskdale and Ewesdale (September 1341) and sought to attach Douglas's military skill and fame to his own by involving William in the two or three raids into northern England which the king made before spring 1342, at first perhaps under the banner of John Randolph then under his own royal colours. However, David also sought typically to use Douglas's influence and ambition to affect the balance of political power in Scotland. Not only did David grant Douglas the vacant earldom of Atholl - forfeited by the Strathbogies and briefly held by the Campbells - on 18 July 1341 whilst at the siege of Stirling, thus snubbing the ambitions of the Steward in this direction; but before February 1342 the Crown also granted Douglas lands in Peeblesshire and the barony of Dalkeith, which last bordered directly onto Dalhousie, the main barony of another rising 'flower of chivalry' and Douglas's main rival in the Lothians and marches, Sir Alexander Ramsay. ${ }^{10}$

This was an early indication that David's patronage was to be calculating, attuned to balancing magnate interests in the various regions of Scotland. Yet his favour must have seemed utterly divisive and partisan in the eyes of established lords like the Steward. For whilst the latter found himself frozen out of royal favour despite his war service as lieutenant, David continued to shower favour on other, lesser knights, many of them among his circle of relatives and close friends, often serving within the royal household, with others obviously lifted out of the Steward's army of the late 1330s. Over the course of the next five years, David's favour to these men - as well as to the secular prelates, monastic houses and burghs of Scotland - amounted to an impressive resettlement after the disruption of the 1330s, bringing in theory considerable loyalty to the Bruce regime and effective delegation of Crown offices in the localities.

Yet inevitably this resettlement was regionally uneven and took hold best in the east-coast Lowlands, the royal heartlands. In the north-east, badly hit by the military incursions of David Strathbogie, Earl of Atholl, and Edward III before 1336, David notably gifted baronies and former thanages to his household knights Philip Meldrum and Adam Buttergask and their brothers, as well as to the Keiths, Murrays (David's cousins), Leslies and the husbands of David's sisters, Robert Glen and William, Earl of Sutherland. Around Angus and the Mearns David favoured a number of lesser knights, including the Ramsays (sheriffs of Forfar), Roger Mortimer of Inverbervie, Sir Walter Moigne, Sir Reginald Cheyne, William Fraser of Cowie (who had helped Douglas of Lothian capture Edinburgh castle in 1341) and, again, the Keiths and the earl of

10 RRS, vi, nos. 31, 32, 36, 247; Registrum Magni Sigilli Regum Scottorum [RMS], i, App. ii, nos. 570, 774, 805, 813, 839, 1127; Exchequer Rolls of Scotland [ER], i, 508; Brown, Black Douglases, 39-43. Douglas had visited David in France in 1339 and returned with royal favour and some French knights (Chron. Bower (Watt), vii, 141-4, 153-5). For David's raids into England 1341-6, see Chron. Bower (Watt), vii, 151-3; Chron. Lanercost, 236. 
Sutherland. There was no royal favour in the north and north-east for the earl of Ross. ${ }^{11}$

However, in central Scotland, the south-west, south-east and the Borders, David's patronage was arguably far more complex and fragmented, with particular men receiving lands in several regions, often perhaps as a deliberate royal check on other magnates. Sir Maurice Murray of Drumsregard, sheriff of Lanark - who had commanded a Scottish division for the Steward at the siege of Stirling - was granted its keeping along with the Lanarkshire barony of Stonehouse, as well as Sprouston and Hawick baronies in Roxburghshire (which last two Robert I had given to his own bastard son, Robert, and the Good Sir James Douglas respectively): all of these lands could be said to border along Steward holdings. ${ }^{12}$ Sir Malcolm Fleming of Biggar, keeper of Dumbarton castle, David's 'foster-father' who had helped the child king escape to France in 1334 , received confirmation of all his lands in the west but also a hereditary grant of a regality earldom of Wigtown on 9 November 1341. In early 1342 Fleming received another grant in this former Comyn-Balliol stronghold, namely the barony of Mochrum in Wigtownshire, lands recently owned by Alexander Bruce, Earl of Carrick, killed in 1333, but held since then by Patrick Dunbar, Earl of March. ${ }^{13}$

The earl of March was by this stage a man in his sixties (born $c .1282$ ) who had played a quiet role during the Steward's lieutenancy. Nonetheless, it is likely that David viewed Earl Patrick as having taken advantage of the royal absence to further his own landed interests. More than that, Dunbar and the Steward were doubly damned in David's eyes for their submissions in the 1330s to Edward Balliol and Edward III. March, who had received no rewards from Robert I for entering his peace $c .1314-15$ or betraying the Balliol conspiracy of 1320 , certainly joined the Anglo-Balliol occupation regime between 1332 and $1335 .{ }^{14}$ March

11 RMS, i, App ii, nos. 729, 782, 791, 842, 892 (Buttergasks); 417, 851, 890, 987, 1104 (Philip Meldrum); 1083-9 (Murray); 414, 415, 515 (John Bonville, sheriff of Aberdeen, c.1342-3); 761, 1020 (Keith); 1103 (Chalmers); 975, 990 (Cheyne); 960 (Glen); 977 (Fraser); 939, 999, 1071 (Maud Bruce/Earl of Sutherland). RRS, vi, nos. 25, 87, 213 (William and Philip Meldrum); 94A (Thomas Lypp of barony of Schivas); 99 (William Abernethy of Rothiemay); 96 (Bruce/Sutherland); RMS, i App. i, no. 121 (Bruce/Sutherland). See also ER, i, 34, 107, 210, 510 (cash to Maud Bruce's first husband, Thomas Isaac, for an unspecified office), 535, 542, and Fraser, Sutherland Book, i, 29-31, and iii, 14-5. David also confirmed some of John Randolph's grants to his affinity (e.g., $R R S$, vi, no. 98 ).

12 For Murray, see RRS, vi, no. 18; RMS, i, App. ii, nos. 775-6, 822, 871, 968-9, 1015, 1097; ER, i, 483, 508, 514, 527, and Chron. Bower (Watt), vii, 141, 145, 261. Robert I had given Robert Steward the Roxburghshire baronies of Eckford, Nisbet, Longnewton, Maxton and Caverton (illustrated in P. G. B. McNeill and H. L. MacQueen (eds.), Atlas of Scottish History to 1707 (Edinburgh, 1996), 103).

13 RRS, vi, nos. 30, 39, 52; RMS, i, App. ii, nos. 738, 869-70, 927, 1149; ER, i, 144-8 et ad indecim; Chron. Bower (Watt), vii, 83, 93, 97; Kervyn de Lettenhove, Oeuvres de Froissart publiées avec les variants des divers manuscrits (Paris, 1870-77), iii, 432-5.

14 For March, see ER, i, 410-53 (keeper of Berwick castle in 1330s); CDS, iii, nos. 1081-82, 1124, 1142; M. Penman, "A fell coniuracioun agayn Robert the douchty King”: The Soules conspiracy of 1318-20', Innes Review, 1 (1999), 25-57, 28, 43-4; R. Nicholson, Edward III and the Scots (Oxford, 1965), 92-101, 150, and ch. 9. Earl Patrick may briefly have 
rejoined the Bruce Scots around the time that the Steward seems to have negotiated protection for his lands by entering Edward III's peace (until perhaps as late as 1338). ${ }^{15}$

To absolve them for their brief defections, David seems to have issued both the Steward and March with a general pardon and confirmation of their lands $c .1341-2 .{ }^{16}$ However, in doing so the king probably exploited the high moral ground to continue to exclude these magnates from royal favour and in several instances to punish them further by depriving them of some lands. The Steward's pardon noticeably excluded confirmation of the valuable lands of Bathgate and Ratho in Lothian which reverted to the Crown; in 1342 the Steward may also have been obliged by the king to resign the lands of Enoch in Dumfriesshire to the crusader and Perthshire knight, Sir Robert Menzies, to whom David would also later give lands in Dull, Perthshire, surely denting there the interests of the Steward (1343-6). ${ }^{17}$

David also favoured a number of knights within the Steward's traditional regional orbit: as well as favouring Fleming and Maurice Murray, between 1341 and 1346 the king gave Lanarkshire baronies to William Murray (Strathaven), William Livingston (Wiston), James Sandilands (Walston), William Jardine (Roberton), John Maitland (Covington) and Alexander Stewart of Darnley (Cambusnethan). Alexander, a cousin of the Steward, was also appointed the king's bailie in Annandale with the right to hear cases involving Annandale men in Clydesdale, the Steward's heartlands. In addition, an Alan Stewart, possibly of Ayrshire lands, would be noted by the Scottish chroniclers for his recovery of much of south-west Scotland from Anglo-Balliol re-occupation in the 1350s, a task he undertook in partnership with Sir John Kennedy of Dunure in Ayrshire, whose clan chieftainship David recognised $c .1342-3$ (along with several others in the south-west). Another Stewart scion, John Stewart, was given Dalswinton in Dumfriesshire and made warden of the west march. David also favoured the Wallaces in Ayrshire and the traditional Bruce tenant families, the Carruthers, Johnstones, Corbetts, Boyds and Annans in Carrick and the west marches. Overall, these grantees, together with David's many other grants to lesser men in western and south-western Scotland, and the Bruce and Randolph presence in Annandale, threatened to box in the Stewart lands. ${ }^{18}$

14 (continued) been lieutenant south of the Forth while Andrew Murray acted north of the Forth before his capture in 1332.

15 Chron. Scalachronica, 100-1; Adae Murimuth (1275-1347) Continuato Chronicum Robertus de Avesbury de Gestis Mirabilibus Edwardi Tertii, ed. E. M. Thompson (London, 1889), 299-300; thanks to Dr Michael Brown for this reference.

16 RMS, i, App. ii, nos. 823 (Steward), 947 (March). The obvious time to issue pardons would have been at the first Parliament at Scone, September 1341, although it is possible that March's confirmation should be dated to $c .1344$.

17 Ibid., i, App. ii, no. 727; RRS, vi, no. 63. Alexander III had bought Bathgate and Ratho from the de Bohun family for $£ 989$ c. 1282 - they were worth about $£ 250$ p.a. at that time; A. A. M. Duncan, Scotland: The Making of the Kingdom (Edinburgh, 1975), 587.

18 RMS, i, App ii, nos. 788, 928, 1032 (Wallaces, sheriff of Ayr, coroner of Carrick); 831, 844, 894-5, 1100 (Gilbert Carrick, coroner of Ayr); 912 (clan Gillolane), 913 (clan 
In much the same way, David continued to exclude the earl of March from lands and offices in south-east Scotland which he offered instead to Alexander Ramsay of Dalhousie and others. This group included Sir John Preston, a key royal household knight after 1357 (Gorton barony outside Edinburgh, January 1342); William More, custodian of the Knights Hospitallers' lands (Abercorn barony); Walter Haliburton, a Ramsay follower and future sheriff of Berwick and ambassador for David; William Ramsay of Colluthie in Fife, Alexander's brother (several lands in Lothian as well as the sheriffship of Edinburgh by c.1343); Bartholomew Loen, bailie of Kinghorn, who would act as a papal ambassador for David c.1349-50 (Barnbougle barony outside Edinburgh); and, again, James Sandilands, another envoy for David c.1346-57 (Peeblesshire lands). David also visited Earl Patrick's Dunbar castle in person in 1342 and began to favour men within his affinity, including the earl's half-brother and heir, Sir Patrick Dunbar (d. 1357), a follower of the knight of Dalhousie as well as a crusader and father of David's future mistress, Agnes Dunbar. ${ }^{19}$

In this manner, by spring 1342 David had quite effectively signalled the return of an active adult king to Scotland and begun to assert the Crown's dominance. Typically he backed up his grants with personal energy, making ayres ranging from the fringes of the south-west (Middlebie and Mousewald) to Inverness and Moray in the north, and back and forth frequently between Edinburgh and Dumbarton. However, it is clear that some regions remained beyond David's control and that his moves to shift the balance of power within these areas of Scotland in his favour provoked an early magnate backlash. ${ }^{20}$

For in a council at Aberdeen in February 1342 - held after David had led a raid into England and hosted an image-boosting tournament in the burgh - the Steward and William Douglas combined to forward their own regional ambitions at the expense of David's balancing act. The Steward

18 (continued) Kenelman), 914 (clan Kennedy), 982 (clan McGowan); 835, 1006, 1007 (MacDowalls, constable of Kirkcudbright); 1081 (Maxwell of Caerlaverock); 755, 838, 910, 1005, 1115-6 (Crawfords); 915, 973 (John Randolph, commendatorship of Dumfriesshire and life justiciary of Annandale/Mann); 830 (Thomas Boyd of Kilmarnock); 1112 (David Annan); 747 (Livingston); 824 (Maitland); 967 (Sandilands); 1010 (John Stewart); 1013 (Jardine). RRS, vi, nos. 38 (Maitland), 94 (Sandilands). Oddly, David II also continued to act as lord of Annandale in rewarding the Carruthers and John Stewart of Dalswinton ( $R M S$, i, App. ii, no. 1010; RRS, vi, nos. 78, 81). RRS, vi, no. 100, RMS, i, App. ii, no. 936, and Chron. Bower (Watt), vii, 269, for Alan Stewart.

$19 R M S$, i, App. ii, nos. 815, 916 (More); 748 (Sir Walter Bickerton); 809, 921 (Haliburton); 902, 962, 1070 (William Ramsay); 1142 (Preston). RRS, vi, no. 41 et ad indecim, and ER, i and ii ad indecim (Preston). RRS, vi, nos. 104 (Loen); 95 (Sandilands); 97 (Maitland, who by the 1360s was the first husband of David II's intended third wife, Agnes Dunbar). For Sir Patrick Dunbar, see Rotuli Scotiae [Rot. Scot.], i, 797; for Bartholomew Loen and Haliburton as envoys, see E. W. M. Balfour-Melville, 'David II's appeal to the pope', ante, xli (1962), 86; for Sandilands as envoy, see Rot. Scot., i, 715, 718, 727, and the king's gift to him of Roberton barony in Lanarkshire in 1349, $R R S$, vi, no. 114; $R R S$, vi, no. 319, for Haliburton as sheriff of Berwick c.1364; NAS, RH 1/2/911, for Ramsay as sheriff of Edinburgh.

20 For David's itinerary 1329-46, see Atlas of Scottish History, 171. 
effectively challenged David's gift or concession of the Border lordship of Liddesdale to Douglas. The king was obliged to agree to the two magnates' exchange (or excambion) of Liddesdale and the earldom of Atholl: this strengthened Douglas in the marches and the Steward in central Scotland respectively. Later in spring 1342 David was also obliged to recognise a tailzie giving the new 'knight of Liddesdale' control of the family lands of his adolescent and exiled nephew, William, Lord of Douglas. ${ }^{21}$

Yet when David did respond to this challenge to his will he only escalated the problem. In March 1342, Alexander Ramsay captured Roxburgh castle. At a Council at Restenneth in June that year, David probably confirmed Ramsay as sheriff of Teviotdale, a move which the Scottish chroniclers concur may have been designed to snub Douglas's territorial concerns. Douglas and Ramsay and their followings had likely been at odds for some time and about June 1342 Liddesdale retaliated by seizing Ramsay during a sheriff court and starving him to death in Hermitage castle. David was only dissuaded from reacting with the full force of his wrath by the intercession of the Steward on Douglas's behalf. Rather than forfeit Douglas (and presumably reverse any excambion deal he had done with the Steward for Atholl) all the king could do immediately was forfeit and arrest Douglas's ally, William Bullock, the chamberlain, mirroring the initial insult by having Sir David Barclay gaol Bullock and starve him to death in Randolph's castle of Lochindorb in Moray. ${ }^{22}$ But in the longer term, Douglas found himself frozen out, his kin deprived of their control of the royal castles and sheriff offices in Edinburgh, Perth and (briefly) Teviotdale in favour of royal household knights. ${ }^{23}$

David was able through patronage and his personal leadership of raids on northern England - and his interest in chivalry and the crusades in general - to win the service of most of Dalhousie's followers. ${ }^{24}$

21

22

ter the Soules conspiracy.

Chron. Fordun, ii, 355-7; Chron. Wyntoun, vi, 160-6; Chron. Bower (Watt), vii, 153-8, records that the Steward made "many interventions and explanations of how much William had suffered in David's absence for the defence and liberty of the Kingdom'. In 1350, Douglas would have David Barclay killed in revenge for the death of his brother, John Douglas, c.1348. Bullock had helped Douglas capture Edinburgh castle.

23 David seems to have appointed a John Barclay as keeper of Roxburgh castle and perhaps also sheriff of Teviotdale for a time in 1342, but it is likely that Douglas took up this castle and office soon thereafter, despite the king's anger. Chron. Bower (Watt), vii, 157; Brown, Black Douglases, 42, 51 note 23.

24 Chron. Wyntoun, vi, 146, names Ramsay's affinity as including the esquires '[Walter] Haliburton, [John] Herries, Patrik of Dunbar and [William] Dischington, [Alexander] Stewart, [Hugh] Eglintoun, [John] Cragy, [Thomas] Boyd and [Adam] Foularton'. For some of David's favour to these men, see above and RRS, vi, nos. 126, 175, 210, 351, 361, 373; RMS, i, nos. 192, 267, 282, 297, 331, 346, and App. ii, nos. 809, 921, 1388, 1563; ER, i, 583, 591, and ii, 112-4, 129, 333, 358; CDS, iii, no. 1576; Rot. Scot., i, 797. Although Eglintoun, a celebrated vernacular poet, would become a brother-in-law and follower of the Steward after 1357 (as did Fullarton), he was given some lands by David before 1346; Dischington would go on to become David's sheriff of Fife and royal master of works in the 1360s; John Herries would receive south-western lands, John Craigie lands in Lothian; Fullarton and Alexander Stewart offered their sons as hostages for David's release in 
However, despite this growth in the royal household and military following, the ability of Robert Steward to resist the royal will is obvious, especially when the heir presumptive combined with other magnates who felt slighted by David. Indeed the Steward's opposition over Liddesdale and Atholl in 1342 was arguably repeated the following year. Writing in the last quarter of the fourteenth century, the English chronicler, Henry Knighton, notes under the year 1342 that:

a dispute arose in Scotland between King David, who had made himself King, and John [MacDonald] of Islay and others there. But King David bowed to their will, for if he had not he would have lost the Kingdom. ${ }^{25}$

This tantalisingly cryptic reference to a major crisis for the Crown seems to refer to the fallout from the king's attempts to interfere in the balance of power in the west coast and inner Hebrides. In late 1341 David seems to have confirmed to the MacDonalds their control of Islay, Jura, Colonsay, Skye and the mainlands (and several castles) of Morar, Kintyre, Glencoe and Lochaber, some of which had been granted to John by his temporary ally King Edward Balliol in the 1330s. But Robert I had granted Kintyre to the Steward and recognised Skye as being possessed by the earls of Ross. In much the same way Robert I had rewarded the Campbells of Lochawe as his in-laws and new earls of Atholl, but in June 1342 David had denied them confirmation of their homelands of Lochawe after their support of the Steward in the 1330s.

However, in June 1343 - while at Ayr - David seems to have been forced to back down from this divide and rule policy. 'After diligent discussion and bearing the peace of our realm in mind', the MacDonalds' lands were confirmed with the exception of Kintyre and Skye, now presumably returned to the Steward and Ross. The king may have been obliged to do this in the face of joint opposition from Steward and Ross who were both at loggerheads with the lord of the Isles, Steward at least until 1350 when John MacDonald became his son-in-law. Similarly, also at Ayr in June 1343, although they had now lost Skye, David confirmed the lands of the MacRuaries of Garmoran (pardoned despite their forfeiture by Robert I in 1325) as well as charters they had recently received from William, Earl of Ross. But it would be Ranald MacRuarie and his followers whom Ross would slay at the muster of the royal host near Perth in $1346 .{ }^{26}$

24

(continued) the 1350s. Chron. Bower (Watt), vii, 151-3, states that during a raid on the Tyne in 1342 'five of his squires whom he knighted there - namely Stewart, Eglintoun, Cragy, Boyd and Fullarton - were carried off as captives ... [but ransomed back by the king with] a great weight of gold.'

G. H. Martin (ed.), Knighton's Chronicle, 1337-96 (Oxford, 1995), 41.

26 RRS, vi, nos. 54, 69, 72-3, 166; RMS, i, App. i, no. 114; J. and R. W. Munro, The Acts of the Lords of the Isles, 1336-1493 (Scot. Hist. Soc., 1986), Appendix nos. 1, A2 and B24; for a possible Steward-MacDonald marriage $c .1343$, see Calendar of Papal Registers [CPR], iii, 381. In 1342 the earl of Ross had also concluded a marriage-peace deal with MacDonald, NAS, RH2/6/4. 
These shadowy dealings are an indication of how far the anger of individual magnates, slighted by David's interference in their regional spheres of influence, could boil over. That in 1343 such opposition to the Crown's will may have been a major worry not only for David but for his chief advisor, John Randolph, Earl of Moray, who surely sought to weaken the influence of both the earl of Ross and the MacDonalds, is suggested by the written royal assurance that MacDonald should continue to hold Lochaber (originally part of the Moray regality) 'free from all action and dispute'.

David and Randolph clearly appear frustrated in many of their efforts to erode the influence of magnates who had prospered during their prolonged absences; their obvious victories appear small beer, if not petty, in the manner of removing Bullock when David really desired to punish Douglas. In the same vein, the Steward seems to have been denied the right to use the title of earl of Atholl. More practically, on 13 November 1342, Pope Clement VI (who as the archbishop of Rouen may have acted as David's advisor 1334-41) backed David's choice of candidate for the vacant church of Rait in Perthshire: David's man, Robert Semple, had presented himself in fear of his life from the Steward's candidate 'to whom the rights did not belong'. Similarly, David may have snubbed the Steward by securing his choice of Richard Pilmor as the new bishop of Dunkeld. $^{27}$

However, it was arguably not until late 1343-early 1344 that David managed to inflict telling damage on the interests of the Steward and others and make it stick longer than his interference in Atholl/Liddesdale. As Stephen Boardman has shown, David was quite successful before 1346 in challenging the Steward's advance into central Scotland, with particular regard to the earldoms which the Stewarts would target after 1346 Menteith, Strathearn and Fife - and their neighbouring lordships. Sometime after June 1341 David recognised Sir John Graham, formerly of Abercorn, as earl of Menteith (by right of his marriage of $c .1336$ ). Then in October 1343 David granted Strathearn to the already well-rewarded Sir Maurice Murray of Drumsregard who had wed the widow of the seventh earl of Strathearn about 1339. ${ }^{28}$

Yet at a Parliament at Scone in June 1344 David found it necessary to have the treason trial of Malise, eighth Earl of Strathearn, reheard: Malise

$C P R$, iii, 67, for David's cleric in Rait, Robert Semple; David II and the Steward would dispute Rait's lands in the 1360s (RRS, vi, no. 421; Penman, 'Kingship of David II', 485-93). For Pilmor, see Watt, Scottish Graduates, 451-2. Edward III had backed a Malcolm of Innerpeffray for Dunkeld; the Steward's man, Duncan de Strathearn, was represented at Avignon by an Alexander Stewart, archdeacon of Ross, and a Stewart of Menteith who would become bishop of Ross in 1350.

28 For Graham's patronage, RMS, i, App ii, no. 815; RRS, vi, nos. 104, 107; Historical Manuscripts Commission [HMC], XI Duke of Hamilton, 219, and HMC Milne Home, 272. For Murray's earldom, see RRS, vi, no. 77; for his marriage, see Fraser, Menteith, i, pp. xl-xc, 100-5, 135. Murray wed Joanna Menteith - daughter of John Menteith of Arran and Knapdale and widow in turn of Malise, 7th Earl of Menteith, and before him John Campbell, Earl of Atholl - as a means of settling a feud with the Menteith Stewarts. 
had already been found guilty - not of treason but of wilfully surrendering his earldom to Edward Balliol - by a parliamentary assize organised by the Steward as lieutenant in 1339. Strathearn would be successfully claimed by the Steward by 1357-8 (through no obvious claim of familial inheritance). But it seems likely that in 1344 David was forced to pack a parliamentary assize with his supporters (men he had favoured since June 1341) to secure control of Strathearn's fate for the Crown so as to rebuff a Steward challenge to Maurice Murray's new title. The fact that Maurice had to be granted the earldom twice, once before and once after this assize, makes it unlikely he was merely elevated as a compromise figure acceptable to both Crown and Steward. ${ }^{29}$

Generally, achieving control of Strathearn's fate in 1344 allowed David to place some of the loyal lesser and household knights whom he had favoured elsewhere in Scotland into central shire lands: for example, the Menzies family, William Towers of Dalry, Hugh Blair and Gilbert Carrick from the south-west, Lawrence Gilliebrand (a Mar man and ambassador to the papacy for David $c .1349-50)$, Philip Meldrum, William Livingston (granted the barony of Callendar in July 1345), Sir John Lyle of Duchal, and the Semples. ${ }^{30}$ Sir Andrew Buttergask, a household clerk and deputy justiciar in the north, became sheriff of Perth. ${ }^{31}$

But David also stepped up his checks on Stewart influence. In September 1343 he pardoned John Logie, son of a conspirator against Robert I in 1320, and restored him to the large lordship of Strathgartney bordering the earldoms of Menteith and Lennox. Strathgartney had been held by Sir John Menteith of Arran and Knapdale's family (cadets of the Stewarts and also former keepers of Dumbarton and guardians of Menteith). After Neville's Cross the Steward as lieutenant would allow John Menteith to recover Strathgartney: this forced David, when he returned from England in 1357-8, to try again to restore Logie's sasine. By 1361-2 David would have found a mistress in Logie's wife, Margaret Drummond, whose family David had already begun to favour c.1343-4: Margaret's brother, Malcolm Drummond, became coroner of Perth and received new lands in the shire, as did their uncle, John Drummond, whom David would make earl of Menteith in 1360 directly denying a son of the Steward. David's favour to the Drummonds must have fuelled the tension between them and the Stewarts and Campbells: this erupted into a full-blown murderous feud by the 1350 s. $^{32}$

David may also have begun to interfere in the several large Perthshire lordships held by the earl of Fife but coveted by the Steward - Strath Tay,

J. M. Thomson, 'A roll of the Scottish Parliament, 1344', ante, ix (1912), 235-40; RMS, i, App ii, no. 896. The 1344 assize included the earls of Fife, Wigtown, Menteith; knights John Maxwell, Thomas Boyd, William Livingston, John Crawford, Andrew Douglas, William Ramsay, David Weymss, Hugh Eglintoun, David Barclay, Alan Cathcart, Robert Menzies, Alexander Cragy, Michael Scot, and three clerics.

30 RMS, i, App. ii, nos. 908, 941, 959, 967, 986, 1016, 1068, 1104, 1127, 1130; RRS, vi, nos. 93-5.

31 RMS, i, no. 196; ER, i, 499-542 passim. Buttergask had been sheriff of Perth $c .1334$.

32 RRS, vi, nos. 75, 212, 327; Boardman, Early Stewart Kings, 16-19; Fraser, Menteith, i, 109-15. 
Strath Braan and Strathord. Yet David's obstruction of the Steward's designs on Fife's lands as a whole may have had deeper political and personal motivation. In 1315 Robert I had accepted Duncan, Earl of Fife, into his peace in return for a tailzie of that earldom which provided for its reversion to an 'assignee of the Crown' in the event of Duncan's death without heirs (although it remains uncertain whether this was intended to exclude Fife's female heirs). Fife's incumbent, of course, played a central role in the coronation of any new king of Scots. For that reason Robert I felt it desirable that ideally the earldom should pass to someone of the blood royal but not likely to be king: Robert may have had in mind a younger Bruce son should he have one, or any sons his own daughter, Marjorie Bruce, might have. Thus it is possible that sometime c.1316-29, Robert I 'assigned' the Fife earldom's future to his new grandson, Robert Stewart (b. 1316), born to Marjorie and Walter the Steward (d. 1326). ${ }^{33}$

If indeed this had been what Robert I, Walter Steward and the community had decided (even unofficially) as a contingency of Earl Duncan's dying without an heir, then Robert Steward must have grown up expecting possibly to inherit Fife. His hopes must have received a dent in the early 1330s when Earl Duncan - who had received no further patronage from the Bruces - renewed relations with his English wife, a granddaughter of Edward I, Maria de Montheremer, and then in 1332 went over to Edward Balliol (crowning him king at Scone) ${ }^{34}$ Yet even when the Fifes produced a daughter, Isabella, possibly nullifying the 1315 tailzie, the Steward may still have held out hope of marrying into a family which would have further strengthened his claim to the Scottish throne (and given him a thin claim to England's).

Under the events of the years $c .1358-60$, the English chronicler Sir Thomas Gray - a captive in Scotland during the Steward's lieutenancy c.1355 - asserts not only that the 1315 tailzie was to come into force if Earl Duncan died without a male heir, but that it was intended that Duncan's daughter, Isabella

should be sold to Robert the Steward of Scotland [for a wife] but she married for love William de Felton, a knight of Northumberland [d. c.1358], who was her guardian at the time, and she laid claim to the earldom which had been renounced by that contract.

Although $c .1359-60$ Isabella would return to Scotland and wed the Steward's second son, Walter, it is possible that in the 1330s and 1340s the Steward had hoped to wed her himself, perhaps as a way of getting round the fact that David had decided $c .1341-6$ to name an alternative assignee to Fife. ${ }^{35}$

33 RRS, v, no. 72.

34 CDS, iii, nos. 8, 1129. B. Webster, 'Scotland without a king, 1329-41', in A. Grant and K. J. Stringer (eds.), Medieval Scotland: Crown, Lordship and Community (Edinburgh, 1993), 223-38, at 226, 229, 234.

35 Chron. Scalachronica, 126; for Isabella after 1357, see Boardman, Early Stewart Kings, 13-15. 
This might explain the uneasy fact that the Steward produced three sons by $c .1340$ (four by 1346) but remained unwed to their mother, Elizabeth Mure: was he holding out in hope of marrying Isabella? One of the Steward's first actions after Neville's Cross was to secure papal legitimation of his relations with, and children by, Elizabeth Mure, probably using David's name and seal without his permission. Besides the distinct possibility that his sons might now become king of Scots after David's capture, the Steward may have been given extra impetus to do so after Isabella of Fife married her English lover, Felton, probably in the late 1330 s or the 1340s. By 1350 the Steward may also have been instrumental in securing the release of Earl Duncan, after his capture at Neville's Cross, long before any other Scottish prisoners (and certainly David) were bought out. Undeniably, the Steward set himself up as guardian of Fife's lands by 1347 (and perhaps even earlier if Earl Duncan's health was waning long before his death in 1353 aged sixty-eight). ${ }^{36}$

That between 1341 and 1346 David must have indicated that he intended to deny the Steward's rightful inheritance to Fife and assert Crown control there also helps explain the considerable amount of patronage David gave to Fife men. The king confirmed and added to the lands in this shire of Alexander Ramsay of Dalhousie, Walter Haliburton (later David's man in Dirleton, East Lothian), David Annan, Roger Mortimer of Inverbervie, David Weymss (sheriff of Fife), and Robert Glen (husband of David's illegitimate sister, Maud, by 1345). David also secured William Landellis, of Fife baronial stock, as bishop of St Andrews in 1342. ${ }^{37}$ But most telling of all, the king was already favouring the two crusading knights whom he would set up successively as earls of Fife after 1357: namely William Ramsay of Colluthie, to whom (as noted earlier) David gave valuable lands in Lothian and the sheriffship of Edinburgh in the 1340s and whom he would impose as earl of Fife in 1358; and Thomas Bisset of Upsetlington, to whom David gave the thanage of Aboyne in

36 Calendar of Papal Petitions [CPP], i, 124, 210; CDS, v, no. 812; Boardman, Early Stewart Kings, 32 note 69, and J. Raine (ed.), Wills and Inventories Illustrative of the History, Manners, Language, Statistics etc., of the Northern Counties of England from the Eleventh Century Onwards, Part I (Surtees Society, 1835), 29, for Isabella's and Felton's son Duncan born probably in the 1340s or 1350s. The Steward's tenant, Robert Erskine, may indeed have been bailie of Fife by $c .1345$ (HMC, vii, 305) - the Steward himself seems to have assumed this office by $c$.March 1347 (NAS, Murthly Castle Muniments GD 121/box 4/Bundle 10/no.3, noticed by Boardman, Early Stewart Kings, 31 note 63). That the Stewarts were upset by David's interference in Fife is suggested by the Steward's burning of timber for royal mills at Crail about 1343 (ER, i, 521).

$37 R M S$, i, App. ii, nos. 760 (confirmation of Earl Duncan grant to Thomas Lumsden); 765 (Alexander Ramsay), 766 (Moneypenny), 889 (Christian Bruce, lands resigned by Earl Duncan), 917 and 976 (David Weymss, resigned by Earl Duncan), 964 (Henry Ramsay), 994 (Nesome Ramsay), 1021 (John Ramsay), 1029 (Glen), 1118 (Chalmers), 1119 (Annan); RRS, vi, nos. 40 (Alexander Ramsay), 62 (confirmation of Earl Duncan grant to Mortimer). Chron. Lanercost, 272, named 13 knights of Fife as attending Edward Balliol's coronation in 1332 with Earl Duncan - David Graham, Michael and David Weymss, Michael Scott, John Inchmartin, Alexander Lamberton, John Dumnore, John Bonville, William Fraser, William de Cambo, Roger Mortimer, John Landellis, Walter Lundie of whom those in italic were rewarded by David 1341-6 and/or killed/captured in 1346. 
Aberdeenshire in the 1340s and would force Isabella of Fife to wed in 1363 (adding to the Stewarts' motives for rebellion in that year).$^{38}$

In the 1340s, then, David clearly sought to deny the Steward his landed succession rights. However, more controversially still, the king may already have become anxious to deny the Steward as his heir presumptive to the kingship, a goal which would obsess David after 1346. Abbot Bower and much later Hector Boece assert that by the late 1350s David wanted to nominate a new royal heir presumptive in John, born sometime in 1346-7, son of William, Earl of Sutherland and David's sister Margaret Bruce (who had been wed about 1342): indeed, John's birth may have been a factor in the Steward's request for a papal legitimation. ${ }^{39}$ Unlike the Steward - born to Robert I's daughter Marjorie, David II's half-sister John Sutherland was a fullnephew of the king. There is no evidence that David attempted to pass a fresh Act of Succession through Parliament to retailzie the kingship after June 1344, a period for which the parliamentary record is missing. But the possibility that David did intend to set up the Sutherlands as an alternative heir presumptive line to the Stewarts may be indicated by the largesse shown by the Crown by 1346 to Earl William and his son: this included a regality for Sutherland itself as well as several valuable thanages and baronies in north-eastern Scotland and around Mar - Kincardine, Aberluthnot and Cluny. ${ }^{40}$

Sutherland's support against the predatory and expansionist William, Earl of Ross, would also have been welcomed by the Crown. ${ }^{41}$ The territorial grants to Sutherland undoubtedly served to counter-balance the lands given to the Ross family by Robert $\mathrm{I}$ in the far north and north-east. ${ }^{42}$ Thus David's brother-in-law may have had some role to play

38 For Ramsay, see above note 20; for Bisset see RMS, i, no. 158, and App. ii, no. 1090. For the crusading careers of these men, see A. MacQuarrie, Scotland and the Crusades, 1095-1560 (Edinburgh, 1985), 82, 84. For David II's interests in the crusades, see Boardman, Early Stewart Kings, ch. 1, and M. Penman, 'Christian days and knights: The religious devotions and court of David II of Scotland, 1329-71', Historical Research (forthcoming 2001).

39 Chron. Bower (Watt), vi, 377; Fraser, Sutherland Book, i, 30-1; The Chronicles of Scotland compiled by Hector Boece, trans. into Scots by John Bellenden, 1531 (Scot. Text Soc., 1938-41), ii, 333. The choice of christian name is itself interesting - all of the alternative heirs David II may have considered were called John - John Sutherland (d. 1361), John of Gaunt, John Stewart of Kyle. Was this an attempt to revive the name first given to David's brother who died in infancy? If this child had been an older twin it surely would have ruled as John I, obliterating the Balliol memory. Some Scottish magnate houses did not baulk at displacing the offspring of a first marriage in favour of the inheritance of children by a second wife, e.g., the MacDonalds (H. L. MacQueen, "The kin of Kennedy, "Kenkynnol" and the common law', in Grant and Stringer, Medieval Scotland, 274-96, at 291).

40 RRS, vi, no. 96; RMS, i, nos. 120-2, and App ii, nos. 970, 1295, 1348; Fraser, Sutherland Book, iii, 12-6.

41 About 1346-7 Margaret Bruce, Countess of Sutherland, had a bastard son by a Mackenzie, feud enemy of the earl of Ross - David would help this child become prior of Beauly in Rossshire (Highland Papers, ii, 13). William, Earl of Sutherland, would eventually be killed $c .1369-70$ in a feud against the MacKays. Froissart's description of Sutherland as 'Earl of Orkney' and the first to join David at the host in 1346 with many men-at-arms, may betray not only the earl's intended new place in the kingdom but also his designs on Caithness and Orkney in opposition to Ross (Oeuvres de Froissart, v, 126-45).

42 Fraser, Sutherland Book, i, 18-21. 
in the Crown's deprivation of the earl of Ross of his office as justiciar north of Forth. For in the Scone Parliament of June 1344 David and John Randolph, Earl of Moray, also seem to have sought validation for their re-assertion of royalist control in this vital office. They may have met stiff and noisy opposition but Parliament still recorded that:

in the presence of the prelates and nobles of the realm Sir John Randolph, Earl of Moray, lord of Annandale and Man, confessed that he had no right to the office of justiciar benorth the Firth of Forth by way of heritage, but for obtaining the said office put himself on our lord the King's will. ${ }^{43}$

This was effectively an enabling act which it is hard to believe David would not have acted upon. There is no evidence extant that Randolph resumed this office before October 1346, although David himself may have taken part in ayres and Sir Maurice Murray, the new earl of Strathearn, received a commission as a justiciar in some region of Scotland during this period. But the Crown could easily have justified Ross's removal: sometime $c .1342-4$ Ross launched a destructive herschip of the Mackenzies' lands, and he may have been hoarding justice receipts or interfering in the collection of the second teinds of the bishopric of Aberdeen, depriving that see's new incumbent, William de Deyn, the former abbot of Kilwinning who had been with David at Château Gaillard. Certainly, although Ross was able to resume the northern justiciarship after Randolph's death at Neville's Cross, in 1358 Ross would be accused of failure to intromit justice profits and was then definitely removed from office by Parliament and replaced with royal household knights. ${ }^{44}$

But Ross suffered further at the hands of the Crown in that confrontational Parliament of June 1344. For Earl William acted as Malise, Earl of Strathearn's attorney in his second hearing for treason out of concern to protect the Ross claim to Malise's other titles of earl of Orkney and Caithness. On 28 May 1344 Malise, Earl of Strathearn (styled thus even though David had given the earldom to Maurice Murray in October 1343), had given Ross, his brother-in-law, control of the marriage of his second daughter. This was a deal which would soon have brought Ross part of the earldom of Caithness, more if he pressed the matter. David's forfeiture of Strathearn in June 1344 may not have had a direct impact on Ross's pursuit of these northern lands, which remained essentially outwith the royal sphere; but David may have tried to poach the loyalty of the Sinclairs of Rosslyn, Ross's intended placemen in Orkney. More

43 Thomson, 'A roll of the Scottish Parliament, 1344', 240.

$44 E R$, i, 543, 546; RMS, i, App ii, no. 968; A. A. M. Duncan, 'The laws of Malcolm MacKenneth', in Grant and Stringer, Medieval Scotland, 239-273, 261; Mackenzie, History of the Mackenzies, 49-52 - c.1346 Ross had Kenneth Mackenzie of Kintail executed. For Deyn, see Watt, Scottish Graduates, 149-50. David also managed to secure another of his ambassadorial servants from 1334-41, Thomas Fingask, as bishop of Caithness about 1342 (ibid., 187-9). 
tangibly, David singled Ross out for personal intimidation. Travelling to the north-east over Christmas 1344 David may have tried to challenge the earl's influence over the burgh of Inverness; David seems to have summoned Ross to his presence at Elgin in November 1345 just after the king had promoted his brother-in-law to a regality in Sutherland. ${ }^{45}$

In several ways, then, the Parliament of June 1344 can be seen as a watershed for David II, John Randolph and their close supporters. The Crown had asserted its will with parliamentary legitimation of the fate of the earldom of Strathearn and the vital justiciarship of Scotia. David now had his choice of officer in the key sheriffships and keeperships of royal castles of the realm and, on paper at least, his widespread patronage amounted to an effective check on the territorial ambitions of the self-made men of the 1330s. For magnates like the Steward, March, Ross and Fife - and, after Spring 1342, the obviously chastened William Douglas, Lord of Liddesdale - the royal court was an uncomfortable, intimidating arena, dominated by David and his favoured nobles, bureaucratic clerics and household knights, men for whom the king in contrast must have represented a figure of generosity and stable authority.

Standard tests suggest David's royal government increased in effectiveness with the passage of time after June 1341. Royal revenue rose: for example, Andrew Buttergask, sheriff of Perth after the removal of Andrew Douglas from that office, took 1142 from the shire for 1343 as opposed to $£ 94$ in 1342; £545 was collected as the fermes of Edinburgh in 1343 - as opposed to $£ 112$ in 1342 - after the removal of another Douglas in charge there. ${ }^{46}$ Royal control of the justiciar ayres might also have boosted David's coffers in 1344-6. David's own court and Parliament also seemed to provide an effective forum for justice with the king himself overseeing the settlement of several magnate disputes with enforced marriages and land deals. ${ }^{47}$ Admittedly, royal income from sensitive areas like the south-west, west coast and far north remained low. But the maturing monarch must have begun to assume a convincing persona as fount of justice and patronage and as Scotland's energetic leader in war, a figure that many Scots found increasingly attractive.

Andrew Wyntoun, a chronicler favourable to the Stewarts, nonetheless employs an anonymous source which depicts David in a favourable light at this time:

Often justyng, dansing and playing He raid with faire court throu all his land chevalrous and worthy

45

Thomson, 'A roll of the Scottish Parliament, 1344', 238; RRS, vi, nos. 85, 99 (Sir William Abernethy given lands in Banffshire).

$46 E R, \mathrm{i}, 502-3,524-6,538-9$ passim. Royal income was still very low, though - in June 1342 the Chamberlain (William Bullock, just before his removal) intromited just £2,529 and Edinburgh's shire was 'waste' that year. There are no extant Exchequer Accounts from mid-1343 to $1353 \mathrm{x} 7$.

$C P R$, iii, 27, 286, 331 . 
stout young and joly,

And yarnyt for to se fechting ${ }^{48}$

David had arguably already shown the 'raddure' - the strong personal authority necessary to control subjects - with which Wyntoun's source would credit his rule between 1357 and 1371. Similarly, Walter Bower insisted that by the eve of the 1346 campaign, the king of Scots was 'fully reassured and supported by the knightly young men of military age'. ${ }^{49}$

However, against this apparent popularity for the returned monarch has to be set the fallout from the Crown's policy of challenging some of its greater subjects' landed and dynastic interests to reassert its own. As Michael Lynch suggests, here there may have been 'signs, less of troublesome magnates, than an inability on the part of an inexperienced King to keep a range of noble interests in balance'. ${ }^{50}$ Wyntoun's source certainly was aware of the discriminating nature of David's patronage:

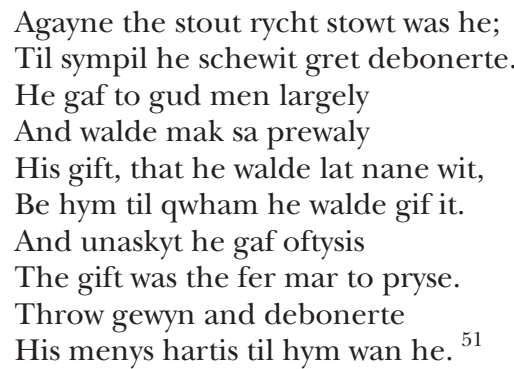

In this context, the behaviour of the Steward, March and Ross in 1346 should have come as absolutely no surprise to David; any hope that they may have had of reward from David's reign must have been long since obliterated - the king had pushed them too far.

In fact, although many benefited from his favour, David's confrontational approach can be said to have added to the disruption and internal rivalries of the Scottish community after the English occupation and intensive war of clearance of the 1330s. In Parliament in June 1344 David also had to bind over the followers of William Douglas of Liddesdale and those of the late Alexander Ramsay (many of whom had entered the royal following) to cease their feuding in the Lothians and marches: the Steward and the earls of Fife, March, Wigtown and Sutherland were named among the cautioners for this peace.$^{52}$ Ross's feud against the Mackenzies and MacRuaries in the north and north-west, Sutherland's

Chron. Wyntoun, vi, 168, 234; see S. Boardman, 'Chronicle propaganda in fourteenth-century Scotland: Robert the Steward, John of Fordun and the "Anonymous Chronicle"', ante, lxxvi (1997), 23-43, for a discussion of the contrasting treatment of the Steward's behaviour $1332-71$ by later writers.

49 Chron. Bower (Watt), vii, 151, 253.

50 M. Lynch, Scotland: A New History (Edinburgh, 1991), 135.

51 Chron. Wyntoun, vi, 241.

52 Thomson, 'A roll of the Scottish Parliament, 1344', 239-40. 
against the MacKays in the same area, and the Stewarts' and Campbells' against the MacDonalds and Drummonds in western and central Scotland, had undeniably been further aggravated by David's land resettlement and rumbled on, worsening into the 1350s. Walter Bower notably spoke of accusations that David's negligence had led to Ramsay's murder, an event Fordun's contemporary source lamented as meaning that:

... feuds and misunderstandings, undying - as it were - and endless arose in the Kingdom, not only among the lords, but even among the common people; so that thenceforth, they murdered each other with mutual slaughter, and slew each other with the sword. ${ }^{53}$

This must have made for an atmosphere of unremitting tension at public gatherings or other collective dealings.

For example, in spring 1344 - just before the momentous Parliament of that year - a pretender Alexander Bruce appeared in Scotland claiming to be the man who had died at Halidon Hill (1333) and laid claim to the earldom of Carrick and other lands as the bastard of Edward Bruce. It is tempting to speculate that this pretender may also have claimed some place in the succession to the Bruce kingship especially if David had cast further doubts over the Stewarts since June 1341. Yet the swiftness with which the Scottish chroniclers report that David was obliged to have this claimant executed in July 1344 at Ayr (after the key Parliament of that year) to placate the land fears of the Steward, Malcolm Fleming, Earl of Wigtown, and others (despite there being 'clear evidence' alleged to substantiate the man's claim) is suggestive of the potentially explosive domestic climate at this time. ${ }^{54}$

The events of the preceding five years must, then, be taken into account for any understanding of the Scottish campaign of 1346. With an awareness of the potential for intensifying personal and factional animosities within the Scottish political community - either in Parliament or at an armed host - it could be said that much of the outcome of David's first invasion en masse of England was predictable.

Whilst he lay asleep with his followers at Elcho monastery as the northern part of the host assembled, Ranald MacRuarie, the island lord most favoured by David II, was murdered by his local enemy, a noble repeatedly diminished by the Crown, William Earl of Ross. According to some chroniclers, despite William Douglas's ironic insistence that the campaign be halted while David deal with this murderer, the army headed south on a

53 Chron. Fordun, ii, 358; Chron. Bower (Watt), vii, 153-5. Bower also highlighted a dispute between a crusader, Alan Wyntoun, and William Murray, keeper of Edinburgh castle, $c .1342-3$, which resulted in 'such disagreement and discord in Lothian that for a year a hundred ploughlands, it is said, could not be cultivated' (ibid., 159).

54 Chron. Fordun, ii, 366-7; Chron. Bower (Watt), vii, 159. 
dirty, scrappy chévauchée of the western and central marches of England (although it is possible it did so after David had reached some pardon deal with Ross who withdrew in shame). Some chroniclers then assert that after the capture of the peel of Liddale in Cumberland, William Douglas whose lordship in Scotland would have benefited most from the removal of this English stronghold - again urged that David turn back. Further uneasy tremors are provided by the contrast between English writers' insistence that David had the captain of Liddale executed unshriven whilst Wyntoun and Bower portray David's dismissal of the veteran Douglas's advice as the error of an inexperienced, impatient general. ${ }^{55}$

David must, though, have had his heart set on making a very definite statement with this campaign. Not only did he desire to repay a debt to Philip VI of France - whose pleading letters for a Scottish attack had arrived with David before the French defeat at Créci (August 1346) - but the king must have seen this as an opportunity to impress his royal authority on all his subjects. Thomas Sampson, an English cleric who reported the result of the battle to his superior, described David as encamping near Durham in 'tents and pavillions of the richest and noblest sort' ${ }^{56}$ If so, this was very definitely to be a royal campaign - almost a progress - and not a traditional guerrilla raid in the style of Robert Bruce, Thomas Randpolph and James Douglas, even though in September and early October 1346, David's army did extract tribute and supplies from several regions in northern England. David's veneration of a Rood of St Margaret (although probably not the original Black Rood, nonetheless held to be a relic of Christ's Holy Cross) as an emblem for his host also points to his desire to exploit the prestige of this campaign. ${ }^{57}$

In the same way - if Alexander Grant's persuasive breakdown of the Scottish divisions is correct - David's deployment of the Steward and March to lead the third and rearguard division when battle was joined in the Bearpark on 17 October may also have been a calculated statement, designed to put his main domestic opponent firmly in his place. The Steward and March led a company of probably 2-3,000 lightly armoured

55 Chron. Fordun, ii, 358-9; Chron. Wyntoun, vi, 172-6; Chron. Bower (Watt), vii, 255-65; Chron. Lanercost, 348-51; Chron. Anonimalle, 23-8; Chron. Meaux Abbey, 60-2 (see translations by Arvanigian and Leopold in Neville's Cross, 132-63). English chroniclers also variously assert that David vowed to take his troops to London, and that in a violent response to his subjects' advice that he turn back, he slew his own page boy.

56 Sampson letter in Oeuvres de Froissart, v, 489-92 (translated in full in Neville's Cross, 134-7); it seems, though, that David spent the night before the battle in the prior of Durham's manor house in the Bearpark (R. A. Lomas, 'The Durham landscape and the battle of Neville's Cross', in Neville's Cross, 66-77, at 72).

57 G. Watson, 'The Black Rood of Scotland', Transactions of the Scottish Ecclesiological Society, ii (1909), 28-47; L. Rollason, 'Spoils of War? Durham Cathedral and the Black Rood of Scotland', in Neville's Cross, 57-65, shows that the Black Rood removed from Scotland by Edward I in 1296 was still in the English treasury in 1346 but that another Scottish Rood found its way to Durham by 1383 . The Rood of 1346 was presumably kept either in the royal household or Holyrood Abbey (which David II had given an extended regality and the right to provide the royal chaplain in 1342-3 [RRS, vi, nos. 59-60]). Robert I had of course also used relics in battle: St Columba's in the Monymusk Reliquary in 1314; St Fillan's arm-bone in 1306-7. 
(mostly Highland/Islands) men. Yet in contrast, Randolph's similarly-sized division with William Douglas, Maurice Murray Earl of Strathearn, John Graham Earl of Menteith and, probably, a reluctant Duncan, Earl of Fife, must have contained up to half of the Lowland mounted chivalry and experienced schiltrom spearmen fielded by the Scots that day, mostly from Moray, Fife, the marches and the south-west of Scotland. David's own division presumably contained a comparable mounted, men-at-arms, and infantry presence from the experienced chivalry of the Lothians (denying the earl of March his natural following) and the Bruce family lands, as well as the earl of Sutherland, Keith the Marischal, Hay the Constable, Scrymegour the standard-bearer from Dundee and other men from the north-east. The fact that Malcolm Fleming, Earl of Wigtown, Lord of Biggar and keeper of Dumbarton is also reported in David's division, and that many men from Lanarkshire also seem to have stayed and fought alongside the king, suggests that a portion of the Steward's own regional following from the west may also have been taken away from him or deserted him for their patron king. ${ }^{58}$

Remarkably, leaving aside the importance of tactics, choice of ground and luck, a clear distinction can be made between those Scots who were killed or captured at Neville's Cross and those who turned tail for home. The list of dead provided by the chroniclers reads like a who's who of David's servants, including John Randolph, Earl of Moray; Maurice Murray, Earl of Strathearn; John Graham, Earl of Menteith, who was captured then executed by Edward III (and who is said to have asked his king for a hundred horsemen to ride down the English archers); Thomas Charteris the Chancellor; Robert Keith the Marischal, David's tutor at Château Gaillard and a sheriff of Aberdeen; John Roxburgh the Chamberlain; and many household knights and regular Crown charter witnesses like Andrew Buttergask, John Bonville, Thomas Boyd, Philip Meldrum, William Haliburton, Edward Keith and several Kirkpatricks, Strachans, Ramsays, Lindsays and lesser Stewarts, all favoured by David since 1341. The available list of those captured, recorded by Edward III's administration, can be similarly catagorised - they were men rewarded by David before 1346; many would be substantially rewarded for their loyalty after 1357. They included almost all of David's Lothian following and their kin, as well as Malcolm Earl of Wigtown, Alexander Stewart of Darnley, John Stewart of Dalswinton, William Ramsay of Colluthie and a number of men of chivalry from Fife, Angus and the Mearns and the north-east. In total, of the eighty-five different individuals named in contemporary sources as captured or killed, records of patronage from the king survive for all but roughly a dozen of the more minor figures. ${ }^{59}$

58 Grant, 'Disaster at Neville's Cross', 30-32 and 26-7, for a very useful table of chronicle accounts of 1346.

59 Many of these 'un-patronised' minor figures were kin to men favoured by David; e.g., Patrick Herries, John Haliburton, Fergus Crawford, etc. For the complete list of dead and captured, compiled from Oeuvres de Froissart, v, 125-6, 148-93; Sampson's letter in Neville's Cross, 136-7; and Rot. Scot., i, 678-9, see Penman, 'Kingship of David II', end of ch. 4 . 
In short, the deserters must have known exactly what they were doing when they withdrew. They had perhaps already seen John Randolph, Maurice Murray and others killed as well as several other Scots magnates captured. The Steward (who would never cross the Border in arms again) must have felt his heart leap at the thought that he might now inherit Menteith, Strathearn, Fife and, of course, the kingship. Patrick, Earl of March, could now look to inherit title to Moray (which he did by 1357) and perhaps exploit William Douglas's capture along with many Lothian men. ${ }^{60}$ All three deserters - the Steward, March and Ross - would exploit ruthlessly the power vacuums resulting from the battle casualties along with William, Lord of Douglas (Liddesdale's nephew, who returned from exile in France $c .1348$ ). After 1357 mounting tension between David and his supporters on the one hand and the Steward, March, Ross and the lord (by 1358 the first earl) of Douglas on the other would focus on lands, offices and matters first disputed before 1346: the earldoms of Fife, Strathearn and Menteith, the justiciarships, various sheriffships and the royal succession. ${ }^{61}$

Further evidence that the dynastic and territorial tensions between David and key magnates had been at the heart of the Scots defeat in 1346 can later be found in chronicle treatments of the battle. As already noted, Fordun's source - by a contemporary of David II's reign - openly condemned the three deserters, as did some of the English writers who may have heard a version of events from David and other Scots captured on that day and lodged in England well into the 1350s. Certainly, David and his supporters would indulge in a rewriting of the unpalatable events of that day through their discussions with Jean Froissart, the Hainault chronicler recommended to David II by Edward III's queen, Philippa; Froissart stayed with the Scottish king and some Scots magnates for several months in $1365 .^{62}$

In Froissart's version, what in reality had been an inglorious Scottish campaign riven with internal tensions became a chivalric exemplum. No mention is made of the role of the Steward, March or Ross in 1346. Instead, prominence is given to David and his close supporters from the 1340s and his 'second kingship' of the 1360s; they are joined at the muster by famous hearty knights from 'Sweden, Norway and Denmark' with the heir and namesake of the great military tutor Alexander Ramsay (who became a celebrated knight in his own right in the 1380s) named as royal standard-bearer. Froissart ascribes David a loyal host of 40,000 men

60 Other magnates like Sir John Menteith of Arran and Knapdale presumably also followed the Steward home, anxious to exploit Malcolm Fleming's capture to secure the keepership of Dumbarton, the sheriffship of Clackmannanshire and the lordship of Strathgartney.

61 Boardman, Early Stewart Kings, 12-25; Penman, 'Kingship of David II', chs. 5-10.

62 J. Palmer (ed.), Froissart - Historian (London, 1981), 26 (Philippa's letter); P. Contamine, 'Froissart and Scotland', in G. G. Simpson (ed.), Scotland and the Low Countries, 1124-1994 (East Linton, 1996), 43-58. Just as Barbour crafted The Bruce for the Stewarts and Douglases, Froissart crafted passages of his Chroniques for his hosts in 1365, David and the Douglases. 
with 3,000 horse which sacks Durham and Wark castles, intent on 'doing some gallant deeds of renown before their return to Scotland', only to be defeated in a straight fight in which the Scottish king acquits himself nobly, knocking out the two front teeth of his eventual captor, John de Coupland, before sustaining - like Philip VI at Créci - two arrow wounds to the face. As he lies badly wounded at Wark (sic) castle, Froissart tellingly has David warn Coupland that unless his wounds are tended quickly the Scots will make themselves a new king tomorrow, a sly reference to the unnamed Steward. Froissart only mentions the latter in his coverage of Franco-Scottish ventures during the Steward's reign as Robert II, by which time David's antagonist was portrayed as a man with

red-bleared eyes, of the colour of sandal-wood, which clearly showed that he was no valiant man, but one who would rather remain at home than march to the field. ${ }^{63}$

More generally, an individual's behaviour at Neville's Cross may have become a litmus test of loyalty to David II and a prerequisite for reward from the king after his return from English captivity in 1357. David would dedicate himself to denying the Stewarts' rights over Fife and the royal succession in that later phase of his reign, as well as continuing to undermine the earl of March/Moray's following and persecuting Ross to the extent of forcing him to tailzie his earldom to a royal crusading favourite, Walter Leslie, in 1368. But those who were captured at Neville's Cross went on to receive large rewards. ${ }^{64}$

Others who were not at the battle but entered David's service after 1357 may also have felt tremendous pressure to plug themselves into such a war record. For example, Sir Robert Erskine, a tenant of the Steward but a canny man who emerges as David II's political and diplomatic fixer in the 1360s - receiving many key offices and valuable nontitle lands - seems to have ensured that Froissart gave him a retrospective fame in the 1330s and 1340s, placing him alongside David's close supporters Randolph, Sutherland, the Ramsays, Flemings and Kirkpatricks in helping the young king escape to France in 1334, return to Scotland amidst mass public celebration and give battle valiantly at Durham: in reality, if Erskine was at Neville's Cross he probably left with the Steward. ${ }^{65}$

63

Oeuvres de Froissart, v, 126-45; P. Hume Brown, Early Travellers in Scotland (Edinburgh, 1891), 8-15.

64 Boardman, Early Stewart Kings, 25, 45-8; Penman, 'Kingship of David II', chs. 3 and 6.

65 Oeuvres de Froissart, iii, 432-5, and v, 127-35. For Erskine's patronage, see RRS, vi, nos $115,117-9,141,146-8,198,207,233,239$, 300, 327, 335, 399, 402, 403, 427, 499; ER, i, $547,573-5 ;$ ER, ii, 50, 77, 120-57; Fraser, Menteith, i, 109-15. After 1350 Erskine held the offices of Chamberlain (1349-50, 1363), sheriff of Stirling, keeper of Stirling and Dumbarton castles, justiciar north of Forth and ambassador to England, France and Rome. Humphrey Kirkpatrick (RRS, vi, no. 189), named by Sampson as killed at Neville's Cross, son of Roger (sheriff of Ayr, captured 1346), can be associated with the abbey of St Dénis and was celebrated by French chroniclers for rescuing David; Paris, Archives Nationales, JJ 74/4757; Les Grandes Chroniques de France, ed. J. Viard (Paris, 1953), ix, 141. 
The Stewarts would have to wait to make their response to this distortion of events. Both Wyntoun (c.1400) and Bower (1440s), writing after the accession of the Steward's dynasty in 1371, stress David's impatient folly in impiously attacking St Cuthbert's churchlands at Durham and failing to heed Douglas's warnings: according to these writers the Steward and March were prudent to withdraw. ${ }^{66}$

However, with the benefit of hindsight it might be argued that David II showed comparable wisdom in learning some lessons from the debacle of Neville's Cross. He never attacked England again, something his personal and diplomatic circumstances as a result of capture made it very difficult for him to do anyway. But David also proceeded against the interests of his Scottish opponents more cautiously after 1357 . Most obviously he never called a national host out in the same manner as he had done in 1346. Indeed, when David had to raise an army against a rebellion by the Steward, March and the new earl of Douglas against the king's lack of 'fair lordship' towards them in 1363, for the first time the Scottish Crown paid for its troops with hard cash supplemented by well directed patronage to loyal household and locality knights. ${ }^{67}$ Nonetheless, after 1357 , as before 1346 , David's discriminatory patronage and badgering manner towards some of his key subjects continued to provoke crown-magnate crises and confrontations. The perenially childless second Bruce king never quite seemed able to exploit these to his full advantage.

Boardman, 'Chronicle propaganda in fourteenth-century Scotland'; Chron. Wyntoun, vi, 178-80; Chron. Bower (Watt), vii, 257-61. 1346 was indeed the only time the Steward crossed the Border in war.

67 Chron. Scalachronica, 173-4; ER, ii, 119-86; RRS, vi, nos. 289 to 312 passim, 293(Ad) and RMS, i, no. 105; Penman, 'Kingship of David II', 378-90. 